\title{
CHARACTERISTICS OF DESASTER PRE LIMINARY RESEARCH \\ IN DEVELOPING LEARNING MODEL OF ENVIRONMENT EDUCATION BASED ON THE DISASTER IN EFFORD TO GROW AN CULTURAL ANTICIPATORY
}

\author{
Ach. Amirudin, Budi Handoyo, Hadi Soekamto
}

\author{
Universitas Negeri Malang \\ E-mail: ach.amirudin.fis@um.ac.id; budi.handoyo.fis@um.ac.id; \\ hadi.soekamto.fis@um.ac.id
}

\begin{abstract}
East Java is one of the region which have a potentialnatural disaster. There are fourpotentialdisastersoccurredinthe region, namelyfloods, landslides, volcanic eruptions, and earthquakes. The disasterproved tohave a negative impacton people's lives. The impact ofthe disasteris due toa lack ofanticipationforcommunities to disastersthatoccurin thereenvironment. Topreventlong-term impact, environmental Education(EE) has astrategic roletoempowerstudents tohaveanticipatoryculture. This study is a preliminary research which aims to identify thecharacteristics of thedisaster which occurredinEast Java and conditions of disaster education at school. Object of the study is floods of the Konto river and landslides at Pujon district and the Kelud eruption at Pandansari Ngantang. This research uses descriptive analysis by reducing data, looking for determinant variables, and takes a conclusion. The research results show the natural disaster in research consists of flooding, landslide, and eruption. Floods and landslides occur on rainy season around December-January. Catastrophic floods caused by heavy rainfall and deforestation. While, the eruption depends on each mountain. The cause of disaster is material of eruption. Status of environment education at school is diverse, there is a region by mandatory local content-based with monolithic approach, and there is also region by elective with integrative approach. Load of the EE subjects is 2 credits, while the school is not compulsory be integrated to the main subject. In this study also be foud tha teachers do not have a EE model for anticipate natural disaster.
\end{abstract}

Keywords: disaster characteristic, Environment education, Cultureanticipatory.

\section{PENDAHULUAN}

Indonesia-Jawa Timur merupakan wilayah yang sering dilanda bencana alam dengan korban yang sangat besar. Ada tujuh bencana alam terbesar terjadi di wilayah ini, yaitu: tsunami Ende, FloresNusa Tenggara Timur, letusan gunung Kelud, gempa bumi Sumatera Barat, tsunami Gunung Krakatau, gunung
Tambora, tsunami 2004 di Nanggroe Aceh (Kompasiana, 2012). Sementara bencana alam dan korbannya yang terjadi dalam dua tahun terakhir di laporkan BNPB (2012), bahwa pada tahun 2011 terdapat 1.598 bencana alam. Jumlah tersebut memang terbilang cukup besar, 
60

Ach. Amirudin, Budi Handoyo, Hadi Soekamto. Characteristics Of Desaster Pre Liminary

Research In Developing Learning Model Of Environment Education Based On The

Disaster In Efford To Grow An Cultural Anticipatory

namun lebih kecil ketimbang 2010 dengan jumlah 2.232 kasus.

Data bencana tahun 2002-2011 menunjukkan bahwa sekitar 89 persen dari total bencana di Indonesia didominasi oleh bencana hidrometeorologi berupa banjir bandang, kekeringan, tanah longsor, puting beliung, dan gelombang pasang. Bencana tersebut telah menimbulkan korban jiwa dan kerugian yang besar orang meninggal dan hilang mencapai 834 orang, mengungsi 325.361 orang, rumah rusak berat 15.166 unit, rusak sedang 3.302 unit dan rusak ringan 41.795 unit. Sedangkan, bencana geologi seperti gempa bumi, tsunami, dan gunung meletus masingmasing terjadi 11 kali ( 0,7 persen), 1 kali $(0,06$

persen), dan 4 kali $(0,2$ persen $)$ berdampak 5 orang meninggal dan rumah rusak sebanyak 7.251 unit. Sementara, pada tahun 2013 triwulan pertama telah terjadi 300 kali lebih bencana, dan ratarata 10 kali bencana terjadi setiap harinya (Kompas, 13 April 2013).

Ada sejumlah faktor potensial yang dapat menjadi penyebab terjadinya bencana di Indonesia, yaitu: (1) letak Indonesia berada di lokasi ring of fire. (2) Indonesia memiliki banyak gunung api.
(3) curah hujan yang relatif tinggi. (4) ulah manusia yang merusak lingkungan alam. BNPB (2013) mensinyalir ada empat ancaman yang menimbulkan resiko bencana, yaitu perubahan iklim global, degradasi lingkungan, kemiskinan, dan bertambahnya jumlah penduduk makin memperbesar ancaman risiko bencana.

MengingatIndonesia memiliki karakteristik wilayah yang berpotensi menimbulkan bencana alam yang telah terbukti menimbulkan korban sangat besar, seharusnya masyarakat Indonesia memiliki budaya antisipasi terhadap bencana alam di sekitarnya. Sebagaimana diunggah dalam Ricky blogspot (2011) bahwa salah satu tindakan antisipatif adalah memberikan edukasi bencana (desaster education), terutama kepada masyarakat yang tinggal di daerah rawan bencana, agar mereka tahu harus berbuat apa menghadapi bencana yang terjadi. Sementara ini, pembelajaran di sekolah masih menerapkan cara-cara yang konvensinal dalam mengantisipasi bencana alam dengan himbauan umum yang kurang mengait dengan sistem pembelajaran di kelas. Sebagai contoh pada bulan Pebruari 2014, status gunung Kelud terus meningkat hingga status 
awas, ternyata dalam pembelajaran di sekolah belum terjadi perubahan apa-apa (Amirudin, 2014).

Pemahaman dan simulasi bencana yang diberikan saat edukasi kebencanaan diharapkan menambah knowledge dan sikap responsif saat bencana betul-betul terjadi sehingga mengurangi jatuhnya korban jiwa yang lebih besar. Hal inilah yang harus dilakukan dalam meminimalisir jatuhnya korban bencana, dengan memberikan edukasi bencana (education disaster) akan memberikan kepekaan masyarakat terhadap bahaya bencana dan sebagai bekal mental diri masyarakat, sehingga masyarakat akan siap bila kemungkinan terburuk menimpanya.

\section{Pendidikan Lingkungan Hidup} (PLH) merupakan suatu proses untuk membangun kesadaran penduduk dan kepedulian terhadap lingkungan secara totaldan segala masalah yang berkaitan dengannya, masyarakat memiliki pengetahuan, ketrampilan, sikap dan tingkah laku, motivasi serta komitmen untuk bekerja sama, baik secara individu maupun secara kolektif, untuk dapat memecahkan berbagai masalah lingkungan saat ini dan mencegah timbulnya masalah baru [UN - Tbilisi,
Georgia - USSR (1977) dalam Unesco, (1978)] dalam Fadli, 2005).

PLH diharapkan dapat menjadi solusi mendasar, komprehensif, dan berkelanjutan melalui implementasi kurikulum, pembelajaran, dan penilaian yang efektif. Namun,realitasnya praktik PLH di sekolah belum mampu menumbuhkembangkan budaya antisipatif terhadap bencana alam sebagai bagian menjaga lingkungan. Pembelajaran PLH masih terfokus pada transfer pengetahuan (environmental knowledge) dan kurang menumbuhkembangkan attitude, skills, dan participation terhadap masalah-masalah lingkungan sebagai bagian utama budaya antisipasi terhadap masalah-masalah kebencanaan. PLH masih menghadapi sejumlah permasalahan, seperti (1) lemahnya

kebijakan pendidikan nasional. (2) lemahnya kebijakan pendidikan daerah; (3) lemahnya satuan pendidikan (sekolahsekolah) untuk mengadopsi dan menjalankan perubahan sistem pendidikan yang dijalankan menuju pendidikan lingkungan hidup; lemahnya masyarakat sipil, lembaga swadaya masyarakat, dan dewan perwakilan rakyat untuk mengerti dan ikut mendorong terwujudnya pendidikan lingkungan hidup; (5) lemahnya proses- 
62

Ach. Amirudin, Budi Handoyo, Hadi Soekamto. Characteristics Of Desaster Pre Liminary

Research In Developing Learning Model Of Environment Education Based On The

Disaster In Efford To Grow An Cultural Anticipatory

proses komunikasi dan diskusi intensif yang memungkinkan terjadinya transfer nilai dan pengetahuan guna pembaruan kebijakan pendidikan yang ada (Sriyandi, 2010). Oleh karena itu, rumusan masalah penelitian adalah (1) bagaimana karakteristik kebencanaan banjir, tanah longsor, erupsi di wilayah Jawa Timur?. (2) bagaimana kondisi pembelajaran kebencaan di sekolah untuk mengantisipasi bencana yang terjadi di sekitarnya?

\section{METODE PENELITIAN}

Secara keseluruhan dalam penelitian ini menggunakan rancangan reasearch and development (R\&D), yakni rancangan penelitian pengembangan dan eksperimen. Namun, dalam penelitian awal yang berfokus pada karakteristik bencana dan PLH ini digunakan rancangan penelitian diskriptif.

Objek penelitian ini adalah bencana alam yang terjadi sungai Konto kecamatan Pujon dan desa Pandansari kecamatan Ngantang kabupaten Malang. Bencana di kecamatan Pujon berupa Banjir dan tanah longsor, sedangkan bencana di Pandansari berupa erupsi gunung Kelud.
Subjek penelitian ini adalah tokoh masyarakat di wilayah yang dilanda banjir sungai Konto dan erupsi Kelud. Selain itu, subjek penelitian ini adalah guru yang sekolahnya berada di area bencana banjir dan erupsi Kelud. Data dikumpulkan dengan dua metode, yaitu observasi dan wawancara. Observasi dilakukan pada area terdampak oleh bencana banjir dan erupsi Kelud. Wawancara dilakukan pada tokoh masyarakat dan guru SD, SMP dan SMA. Analisis data dilakukan secara diskriptif dengan melakukan reduksi data, menemukan keterkaitan antara valiabel, dan menarik kesimpulan.

\section{HASIL PENELITIAN DAN PEMBAHASAN}

\section{Karakteritik Bencana}

Karakteritik kebencanaan dalam penelitian ini meliputi bencana banjir, tanah longsor, dan erupsi Kelud. Masingmasing bencana diuraikan berkaitan dengan jenis dan corak, lokasi dan sebaran, faktor penyebab dan proses terjadinya.

\section{$\underline{\text { Banjir }}$}

Banjir yang terjadi di sungai Konto meliputi banjir Bandang dan banjir biasa. 
Kedua jenis banjir tersebut terjadi pada setiap tahun, setidaknya dalam waktu satu dasawarsa terakhir. Pada banjir bandang, debet air sangat besar, diikuti material anorganik berupa lumpur, pasir, kerikil dan batu yang berukuran relatif besar hingga $150 \mathrm{~cm}$ diameternya. Selain itu, banjir bandang tersebut juga mengangkut material organik berupa pohon yang tumbang yang berdiameter $60 \mathrm{~cm}$, tenaman sayuran, dan rerumputan. Pada banjir biasa umumnya mengangkut material anorganik. Material anorganik yang diangkut berupa kerikil, pasir, dan lumpur. Ukuran material yang diangkut banjir ini tidak terlalu besar dan berat. Batu yang diangkut berdiameter hingga $20 \mathrm{~cm}$. Material yang dominan berupa pasir dan lumpur.

Di kecamatan Pujon terdapat tiga titik bencana banjir yang berdampak signifikan terhadap kehidupan sehari-hari penduduk/masyarakat. Dampak banjir di lokasi-lokasi tersebut sebagai berikut.

\section{Tabel 01 Bencana Banjir}

\begin{tabular}{|c|c|c|}
\hline NO & LOKASI & BENCANA DAN DAMPAKNYA \\
\hline 1 & $\begin{array}{l}\text { Desa } \text { Bendosari } \\
\begin{array}{llll}06 & 56 & 330 & \mathrm{~S} \\
\text { dan } & 91 & 30 & 100 \\
\text { E } & & & \\
\end{array}\end{array}$ & Jembatan hancur kena terjangan banjir bandang sungai Konto \\
\hline 2 & $\begin{array}{l}\text { Desa Bendosari } \\
0656072 \mathrm{~S} \\
\text { dan } 9129970\end{array}$ & $\begin{array}{l}\text { Belokan sungai tererosi arus air yang deras hingga memakan sampai } \\
\text { separo jalan. Kerusakan ini menyebabkan buka tutup kendaraan } \\
\text { yang lewat }\end{array}$ \\
\hline 3 & $\begin{array}{l}\text { Desa Bendosari } \\
06 \quad 55668 \quad \mathrm{~S} \\
\text { dan } 9129744\end{array}$ & $\begin{array}{l}\text { Belokan sungai terkikis hingga } 60 \mathrm{~m} \text { menyebabkan lebar jalan me- } \\
\text { nyempit. Selain itu, seratus meter di bawahnya juga terjadi pengikis- } \\
\text { an dinding jalan hingga memakan lebih separo jalan. }\end{array}$ \\
\hline
\end{tabular}

Bencana banjir yang terjadi si sungai Konto berlangsung setiap musim hujan pada bulan Desember hingga Januari. Sementara, bencana banjir bandang terjadi terjadi pada tiga tahun terakhir 2013/2014, 2011/2013, dan 2010/2013. Banjir bandang berlangsung pada akhir bulan Desember atau awal bulan Januari.
Bencana banjir yang terjadi di sungai Konto akibat dua faktor penyebab, yaitu: curah hujan yang tinggi diatas curah hujan biasanya dan dalam waktu yang lama dan penurunan tumbuhan penutup lahan akibat alih fugsi lahan hutan menjadi lahan budidaya. 
64

Ach. Amirudin, Budi Handoyo, Hadi Soekamto. Characteristics Of Desaster Pre Liminary

Research In Developing Learning Model Of Environment Education Based On The

Disaster In Efford To Grow An Cultural Anticipatory

Bencana banjir sungai Konto menimbulkan berbagai dampak terhadap lingkungan alam sekitar sungai dan kegiatan ekonomi penduduk. Dampak alami yang terjadi berupa kerusakan bantaran sungai, kerusakan sempadan sungai, kerusakan lahan pertanian, dan kerusakan jembatan. Banjir sungai Konto menimbulkan kerusakan bantaran dan sempadan sungai di empat titik di desa Bendosari Pujon. Akibat pengikisan air yang deras dinding-dinding sungai hancur, kemudian merusak area bantaran

Tabel 02 Bencana Longsor sungai dan sempadan sungai sehingga permukaan jalan ambrol atau nyaris ambrol. Hal itu menyebabkan gangguan transportasi, gangguan kegiatan ekonomi, gangguan pendidikan, gangguan kegiatan rekreasi.

\section{Tanah Longsor}

Bencana longsor yang terjadi berupa longsor tebing jalan, sungai, dan tebing perbukitan hutan. Lokasi dan penyebaran tanah longsor terjadi di beberapa lokasi di kecamatan Pujon.

\begin{tabular}{|c|c|c|}
\hline No & Lokasi bencana longsor & Diskripsi \\
\hline 1 & 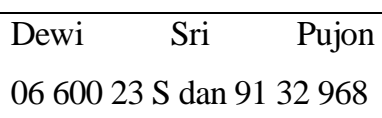 & $\begin{array}{l}\text { Tebing jalan sebelah kiri dari arah Pujon mengalami } \\
\text { longsor sepanjang kurang lebih } 30 \mathrm{~m}\end{array}$ \\
\hline 2 & 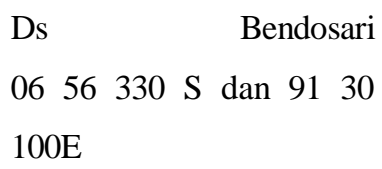 & $\begin{array}{l}\text { Tebing jalan sebelah kiri dari arah Pujon longsor sepan- } \\
\text { jang } 15 \mathrm{~m}\end{array}$ \\
\hline
\end{tabular}

Secara umum bencana tanah longsor terjadi pada musim hujan yang diawali pada bulan Oktober hingga April. Tanah longsor terjadi pada saat curah hujan memuncak sekitar bulan Desember hingga Januari. Bencana tanah longsor disebabkan oleh beberapa faktor: (1) curah hujan yang tinggi dan relatif lama. (2) jumlah pohon/tanaman penutup tanah yang semakin berkurang. (3) Alih fungsi lahan di area yang berkemiringan tinggi. (3) getaran tanah akibat kendaraan besar.

Tanah longsor terjadi di area-area yang bertebing curam. Pada bagian permukaan tanah tumbuhan penutupnya mulai berkurang. Longsor dalam waktu cepat yang didahului oleh hujan yang lebat dan berlangsung dalam waktu yang lama. Air hujan sampai dipermukaan tanah, sebagian meresap ke dalam tanah 
dan sebagian mengalir di permukaan. Air yang meresap ke dalam tanah melalui pori-pori tanah membasai tanah hingga dalam dan mengakibatkan tanah menjadi lembek. Air di permukaan mengalir mengerosi permukaan. Dengan hujan yang lebat dan lama tanah yang lembek dan tererosi tidak kuat menahan beban beratnya hingga terjadi longsor.

\section{$\underline{\text { Erupsi }}$}

Erupsi yang terjadi adalah erupsi eksposif akibat letusan gunung Kelud. Bencana tersebut terjadi di desa Pandansari kecamatan Ngantang yang berlokasi pada lintang $0648083 \mathrm{~S}$ dan 9127447 E. Desa tersebut terdiri lima dusun: Plembong, Bales, Kutut, Pahit dan Munjung. Bencana letusan tersebut dirasakan setiap kali gunung tersebut meletus, sejak tahun 1951, 1968, 1990, 2007, dan 2014. Dari lima kali letusan gunung tersebut, letusan yang paling besar dirasakan adalah letusan pada tahun 2014, sementara letusan-letusan sebelumnya tidak menimbulkan dampak yag berarti.

Bencana erupsi api ini disebabkan oleh material gunung kelud. Material yang dimuntahkan gunung tersebut berupa batu, kerikil, pasir dan debu menutup desa Pandansari dan sekitarnya. Material tersebut menimpa atap rumah penduduk hingga menyebabkan runtuh dan berdampak pada masyarakat desa tersebut.

Proses bencana erupsi desa Pandansari terjadi dalam waktu yang sangat cepat. Pada malam itu menjelang tengah alam terlihat kilatan apai yang terang di atas puncak gunung Kelud. Kilatan yang demikian terang sangat menarik penduduk desa Pandansari dan sekitarnya. Maka penduduk keluar rumah untuk menyaksikan pemandangan tersebut. Setelah berlangsung 5 menit, secara tiba-tiba material pasir, kerikil, dan batu diikuti debu menutup atmosfer Pandansari, dan kemudian menimbun atap rumah penduduk sehingga satu demi satu atap runtuh. Semburan material letusan terus berlangsung hingga dini hari, terpaksa listrik dimatikan, suasana gelap, panic berlangsung hingga siang hari besuknya.

Bencana erupsi telah menimbulkan akibat berupa (1) lahan pertanian tertutup pasih hingga $40 \mathrm{~cm}$ yang menyebabkan tanaman tidak dapat tumbuh baik atau kalau tumbuh jadi kerdil dan menguning. Tanaman tomat dan cabe mengering, (2) atap rumah roboh, (3) hewan ternak terganggu produksi susunya, gangguan kesehatan dan sampai ada yang meninggal. (5) jembatan penghubung 
66

Ach. Amirudin, Budi Handoyo, Hadi Soekamto. Characteristics Of Desaster Pre Liminary

Research In Developing Learning Model Of Environment Education Based On The

Disaster In Efford To Grow An Cultural Anticipatory

keluar desa tertutup lahar dingin sehingga

terisoler untuk beberapa waktu.

\section{Kondisi Mata Pelajaran PLH dalam}

\section{Struktur Kurikulum Sekolah}

Kondisi mata pelajaran PLH yang dibahas dalam penelitian ini mencakup status mata pelajaran, pendekatan, bobot, muatan dan strategi pembelajaran.

\section{Status Mata Pelajaran}

Status mata pelajaran PLH di wilayah penelitian bervariasi. Ada daerah yang menetapkan sebagai muatan lokal yang berkedudukan wajib, tetapi ada pula daerah yang menjadikan mata pelajaran ini sebagai mata pelajaran pilihan/peminatan.

\section{Pendekatan Pembelajaran}

Pembelajaran PLH berlangsung dengan dua pendekatan, yaitu pendekatan monolitik dan integratif. Pendekatan monolitik digunakan pada sekolahsekolah yang menempatkan status PLH sebagai muatan lokal yang wajib. Sedangkan pendekatan integratif berlangsung di sekolah-sekolah yang menempatkan PLH sebagai mata pelajaran pilihan.

\section{Bobot Mata Pelajaran}

Mata pelajaran PLH memiliki bobot

2 SKS bagi sekolah yang menjadikan mata pelajaran ini berstatus wajib. Sedangkan bagi sekolah yang menempatkan PLH tidak wajib, beban pelajaran menyatu pada mata pelajaran yang menjadi 'induk' integrasi.

\section{Strategi-Model Pembelajaran PLH}

Dalam pembelajaran guru-guru di wilayah bencana belum memiliki model yang secara khusus dirancang untuk megantisipasi terjadinya bencana alam. Tidak ada persiapan pada masa pra bencana, saat berlangsung bencana, dan pada masa pasca bencana.

\section{KESIMPULAN}

Hasil penelitian ini menghasilkan kesimpulan bahwa jenis bencana alam yang digali dalam penelitian ini adalah banjir, tanah lonsor, dan erupsi g Kelud. Banjir dan longsor terjadi dipuncak musim hujan sekitar Desember-Januari. Bencana banjir disebabkan oleh curah hujan yang tinggi dan kerusakan hutan. Sedangkan bencana gunung api disebabkan oleh semburan material gunung api yang berupa debu, pasir, kerikil, dan batu, status mata pelajaran PLH di wilayah penelitian bervariasi, ada daerah yang menetapkan sebagai muatan lokal yang berkedudukan wajib, 
tetapi ada pula daerah yang menjadikan mata pelajaran ini sebagai mata pelajaran pilihan/peminatan. Pembelajaran PLH berlangsung secara monolitik dan integratif. Mata pelajaran PLH memiliki bobot 2 SKS bagi sekolah yang menjadikan mewajibkan PLH, sedangkan bagi sekolah yang tidak wajib, bebannya menyatu pada mata pelajaran yang menjadi 'induk' integrasi. Dalam pembelajaran guru-guru di wilayah bencana belum memiliki model pembelajaran yang secara khusus dirancang untuk megantisipasi terjadinya bencana alam, dan karakteristik bencana banjir, tanah longsor, dan erupsi gunung kelud tersebut akan dijadikan sebagai masukan untuk merencanakan model pembelajaran PLH yang berbasis kebencanaan.

\section{DAFTAR PUSTAKA}

Anonimous, 2012.Pencemaran Air Sungai Parah diakses melalui (http://www.seputarindonesia.com/edisicetak/content/vi ew/477505/ diakses tanggal 22 September 2012).

Amirudin, A. 2010. Prinsip-Prinsip embangunan Berkelanjutan. Bahan Ajar. UM: Tidak diterbitkan.

Anonimous, 2012. Antisipatif dengan Edukasi Bencana. (Online) (http Rickyblogspot diakses 7 April 2013).
Anonimous. 2012. Langkah-Langkah Menghadapi Gempa Bumi dan Bencana Alam. (online), (http://idid.facebook.com/permalink.php?sto ry $\mathrm{fbid}=390988940914601 \& \mathrm{id}=38$ 9562314390597, diakses 8 April 2012).

Arsyad, dkk. 2008. Penyelamatan Tanah, Air, dan Lingkungan. Jakarta: Penerbit Obor

Fadli, A. 2005. Pendidikan Lingkungan Hidup: Bukan untuk pembebanan baru bagi siswa, (online) (http://timpakul.web.id/plh-4.html diakses 3 Maret 2013.

Gugus Tugas Pengarusutamaan Pengurangan Risiko Bencana dalam Sistem Pendidikan Nasional. 2010. Strategi Pengarusutamaan Pengurangan Risiko Bencana di Sekolah. Jakarta: Kementrian Pendidikan Nasional.

Izadakh, Yasamin O dan Marla A Petal. 2008. Concept Note: Formal and Informal Education for Disaster Risk Reduction. (Online). (www.riskred.org/ activities/addredislamabad.pdf).

Kompas, Banjir meluas dan tebar ancaman. 13 April 2013 p.1.

Muslim, Dicky, dkk. 2011. Activities on Disaster Awareness Education in the School around Geological Hazard Prone Areas in Indonesia. (Online). (www5.ocn.ne.jp/ nei/images/disas ter1.pdf). Diakses tanggal 29 Mei 2013.

Rusilowati, A, dkk. 2012. Mitigasi Bencana Alam Berbasis Pembelajaran BervisiScience Environment Technology and Society. Jurnal Pendidikan Fisika Indonesia. 8:51-60. (Online). (journal.unnes.ac.id/nju/index/php/JPFI/ 
68

Ach. Amirudin, Budi Handoyo, Hadi Soekamto. Characteristics Of Desaster Pre Liminary Research In Developing Learning Model Of Environment Education Based On The Disaster In Efford To Grow An Cultural Anticipatory

article/view/1994). Diakses tanggal

27 Mei 2013.

Saukah, Ali. 2000. Pedoman Penulisan

Karya Ilmiah. Malang: UM. 